\title{
Integrity and Values
}

\author{
Dr. Jim Sinegal
}

Costco Wholesale Corporation

$I$

$n$ the spring 2007 issue of The New England Journal

of Entrepreneurship, my coauthor and I explored the

intersection of faith and business practices with $S$.

Truett Catby, founder and chairman of Chick-fil-A. Mr.

Cathy is a devoted Southern Baptist, but the interviews with bim led me to consider how members of other faith traditions who bave built successful enterprises see the role of their faith in their entrepreneurial endeavors.

Jim Sinegal is cofounder and CEO of Costco Wholesale Corporation, better known as simply Costco. Since its beginnings in 1983 in Seattle, Washington, Costco bas risen to be the top warebouse-club retailer in the nation, with more than 500 stores in the United States and abroad. The company is known as much for its low prices as the relatively low salary taken by its cofounder (under $400 K)$ and the relative high salaries paid to its cashiers (\$17 per bour).

The company, and Sinegal, has emerged as an example for others to follow. Costco was even mentioned in the 2008 Presidential debate in New Hampshire beld on January 5, as a company that "does it right." The question that I wanted to explore with Sinegal is, why-when so many seem to get it wrong-is his company so different? And, like the practices that make Chick-fil-A and S. Truett Catby different, are those practices rooted in a religious or spiritual framework?

In describing bis success, Sinegal attributes it to "just good business practices." And while be was born into a Catbolic family and supports Catbolic causes, be does not necessarily tie bis faith to the way be approaches business. That approach, be says, is based in learning bow to do business with integrity and high values from an early mentor: The following interview outlines bow Sinegal approaches business and how be works to establish integrity and bigh values throughout Costco Wholesale Corporation.

\section{NEJE: Tell us about your company.}

Sinegal: My partner and I started it in Seattle in 1983. I was living in Southern California at the time. We had concluded that Seattle would be a good market because of the rather low level of competition from a pricing standpoint. We got ourselves established in our business. Very early on

we applied for a license to sell beer and wine in the state of Washington, but we were meeting with all sorts of obstacles. After a period of time, it became very clear that they were trying to stop us from selling [beer and wine]. They would come in and run an audit on our books and looked at all sorts of things like what [price] we were selling milk for. They investigated all sorts of things that were not even associated with liquor and selling beer and wine. It became very obvious that our business would always be subject to scrutiny because of the nature of it and because we were asking people to pay a membership fee and because we were offering great prices on all sorts of branded merchandise. So we understood that there would always be a lot of questions and lots of skepticism on what we were all about.

So we decided that we were going to structure our business in a fashion that would overcome any of the objections that people would have. We were going to guarantee every single product that we carried unconditionally and additionally we were going to guarantee the membership if anybody was unhappy with it at any point. We were not going to carry any seconds or irregulars or poor quality merchandise. We were not going to engage in superlatives or advertising. We don't advertise anyway, so that was a pretty easy call. We were not going to have anybody claim or suggest that the only way that we were profitable was because we were making money off the backs of our employees and that we were not paying them properly. We established our code of conduct at that time.

We believe that there are four things that every business has to do (1) obey the laws, (2) take care of its customers, (3) take care of its people, and (4) respect the suppliers. And if [the business] does all those things, pretty much in that order, they will do what they ultimately have to do as a public company or as a corporation, which is reward the shareholders. Our view is that you can reward the shareholders in a short term by not paying attention to one of those aspects, but you can't do it in a long term. Sooner or later you are going to stumble very badly. You are either going to have labor problems, or you are going to break the law, or your customers are going to be turned off, or the suppliers are not going to want to do any business with you. You have to rec- 
ognize that all those things in a long-term view are important.

Over the period of time since we went public, which is now more than 20 years, we have increased the price of our stock on an 18.5 percent compounded annual rate. We think that's pretty good. If most of us had an opportunity to invest in something that was going to guarantee that type of return over 20 years, we would be pretty pleased with it.

\section{NEJE: I agree.}

Sinegal: And we have been very fortunate. I am not trying to dismiss the fact that an awful lot of good luck goes into being a successful businessperson. It is not intended to be trivial when I say that. I do believe that there are lots of great businesses and smart businesses that fail for one reason or another, sometimes for things beyond their control. We had some good fortune. But we also always paid attention to those four elements of the business. Those were the four things that we had to do and you know it was pretty simple to follow from that standpoint.

If you think about it, you don't have a choice of whether you are going to obey the law; you just have to. If you don't take care of your customers, you are not going to be in business very long. And certainly, having disgruntled employees and having a labor force that is unhappy with you, not only makes it unpleasant to go to work, but it makes it unpleasant for your customers as well. So, we've been pretty mindful of that. We have always loved and viewed our businesses as something that we wanted to build for a long term. We are the company that wants to be here 50 years from now. We want to still be thriving. We want our employees to know that they can build their careers here, that they can count on us being here and that we are not going out of business. For the suppliers likewise, we want them to know they can count on our business into the future. We want the communities where we are doing business to know that our buildings are still going to be around and we still are going to be employing people in the future and those are all commitments that we have.

We have been very fortunate that we have grown from 1983 when we opened our first Costco. This past year our sales were just over $\$ 60$ billion; we've been very profitable. We will continue to grow our business. We have 132,000 employees worldwide and we promote almost exclusively from within our company. We always had the adage that if you hire good people, give them good jobs, pay good wages, and provide good careers, then good things will happen in your business.

I believe that one of the greatest contributions that my partner and I have made to the business is the fact that we've assembled a management team and built a management team that is capable of running a company this size.
NEJE: If I interviewed 100 CEOs and people who bave started and developed their companies to your size, I would probably bear a lot of what you bave said from 99 of those companies. So I am going to pusb you a little bit. Because there has to be something that you are doing differently-different from your nearest competitor, Sam's Club. I am trying to get at what is undergirding your success beyond just the framework of bow you think about it.

Sinegal: Well, I think you have to put it into action. You can't just say you are going to take care of everybody. It is not just a fancy slogan that you can pin on the wall. You can go into any corporation in America and you are going to see a set of values somewhere near the entrance. The question is whether it is just something that you put up for show and the cosmetics, or whether it is really something that the organization believes in. We try to make it something that we believe in. Everybody understands that one of the ways that you can get in trouble is if you break the law; there is no exception. We are not going to wink and suggest that somebody put their thumb on the meat scale and make another $\$ 10$ for us. This type of behavior not only is not tolerated, but you are going to get yourself in trouble.

We expect commitment in everything that we do. You have to make it very clear to everyone. You have to rehearse, refresh, and renew yourself continually on all of these aspects.

\section{NEJE: You have stores in the United States and other countries.}

Sinegal: We are in 8 countries and 39 states, with a total of 504 stores.

NEJE: With an operation that large bow do you ensure or bow does the management team ensure that this philosophy and information is disseminated across the organization?

Sinegal: We make it a major purpose of our business. Generally speaking, employees know when you are being a phony. If you tell them you are not going to break the law, but at the same time they see you are doing things to dismiss any requirements for landscaping a new location, they pretty well get the message that this is a bunch of baloney. They do not believe in what you are saying. They see that you are obeying the law to the extent that you don't get caught.

Obey the law means obey the law. We have challenged the laws in the past when we thought that they were unjust. But we've done it knowingly with our eyes open and with a premeditated purpose at challenging it. We had a couple of lawsuits when we thought that the law was incorrect. One of them was in the state of Washington when the beverage control board passed the regulation that you had to sell beer and 
wine with a minimum of 10 percent markup, and they conveniently excluded themselves from having to comply. We felt that this was a violation of antitrust laws and we challenged the law. We purposely priced beer and wine below 10 percent so that they would cite us and we could take them to court. Those are rare instances in which this would happen, but there are instances when it is important to challenge the law. Rosa Parks was a classic example. Ours was not quite as dramatic, but nonetheless it was a challenge.

That type of spirit runs throughout our organization and people are watching on a continual basis. If they know that an employee is being treated unfairly, that becomes an indictment against the entire organization. If you knowingly mistreated an employee, everybody is going to know about it and everybody is going to question your values relative to the people who are working there. Such a situation suggests that if they can do it to them, then why can't they do it to me? You try to avoid it. None of this is to suggest that there are not instances when the employee needs to be disciplined and that the suppliers need to be discontinued. But you are trying to be fair and expect to be treated as fair as possibly in return. And you reinforce it every day. Believe me, you are being watched every day. Pretty soon people get the message and after a certain period of time, they do know that you mean it. And, they are happy to get on board with it.

NEJE: I would like to ask you a personal question. Are you just attributing to good business sense your success or is there a particular faith that undergoes how you approach your business?

Sinegal: I was raised and educated as a Catholic. I would not suggest to you that I am a practicing Catholic today, although I still consider myself a Catholic. I am involved in many Catholic charities, mainly because I have that background. I am a trustee on the board of Seattle University, a Jesuit University. But I think it's been my business training. And I think it's been a sense of values that have been raised in my business training. I had the good fortune of working for a wonderful boss, whom I learned almost everything from in terms of sense of values and integrity. In the final analysis, it is just good business.

NEJE: There are a number of companies where people have been trained in business and they are not speaking the same language that you are speaking.

Sinegal: When I was 18, I had the good fortune to work for and be trained by a gentleman who had the highest sense of integrity and values. That rubbed off. It was part of my whole business acumen if you will, my education in business, and this was the right course of action. You feel comfortable about what you do and about yourself when you are making decisions in that fashion.
NEJE: Explain your tbinking about wby you don't advertise and the value of advertising.

Sinegal: In our business advertising is cost. If you advertise, you have to raise the price of the merchandise-it is that simple.We are working on margins that do not allow us to spend 1 or 2 percent on advertising.

Also, advertising becomes like a drug. I use the expression: It's like heroin, once you start doing it, it is very hard to stop. We feel that the most successful type of advertising is word of mouth. When people are saying good things about you, it is much more important than when you say them about yourself.

One of the comments that we get across the country from all sorts of major communities is that you guys are the conversation of cocktail parties. Someone is saying, "Gee, you know I got a Coach bag down at Costco the other day." When people talk like this with their neighbors, they admire your company. That gets us more business than anything else that we can do. When you get people talking about you that way, it is irreplaceable. There is no way to replace this type of concept.Word of mouth is the most effective type of advertising.

NEJE: So for those who are spending \$2.6 million on 30 seconds of high-profile ads like those aired during the Super Bowl, where would you say their money would be better spent as opposed to spending it on that type of advertisement?

Sinegal: This concept is good for our business. I don't know if it is good for everyone else's. I think that's what is exciting about American commerce. There are so many ways of doing business-and so many creative ways of doing it. I certainly will not be criticizing some of the advertising and people naming stadiums and stuff like that. That works for them. It does not work for us. And, what we do may not work for them. It does not make us right and them wrong.

NEJE: My last question...what do you wish I had asked you about that I have not?

Sinegal: The question that I am asked the most is: Did you ever think you would ever get so big? That you would grow from 0 to 504 Costcos, doing $\$ 60$ billion. My answer is no. When we started out, we thought we would be lucky if we opened 20 or 30 of these places and grow the business. A lot of good things happened to us. We've been fortunate and we have wonderful people working for us.

Another question that people ask on an ongoing basis is: What worries you the most about the business going forward? And my answer is always that I worry most about maintaining the discipline necessary to do the business under the type of margin that we work on. I worry that we don't lose sight of what it is that got us to where we are and continue to keep the same values. 
NEJE: Your comment triggered another question. What would you want to be said about you? I discovered that your employment contract with the company is rather unique. It is only one page and you put in there that you can be terminated for lack of performance. Sinegal: That's right.

NEJE: I am going to assume that people are happy with your performance until you decide that it is time for you to leave. The question becomes what do you want to be said about you, your personal legacy said by people who worked at Costco or across the business community?

Sinegal: I could refer to Warren Buffet. He said that in his eulogy he wanted people to say,"My God he was old!" I think it's important that you are not being ennobled or enlarged before or after you live. We started a good business and we did everything to perpetuate it for the security of everybody and for all the stakeholders. I think that is the legacy I would like to leave.

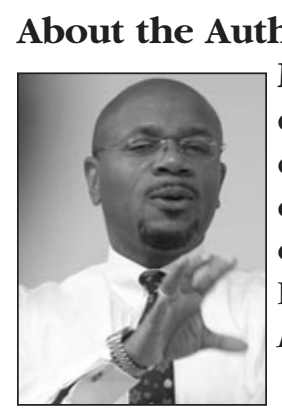

NEj̉E

Miles K. Davis (mdavi3@su.edu) is an associate professor of management at Shenandoah University and is director of the Institute for Entrepreneurship at the Harry F. Byrd, Jr. School of Business. He teaches courses on entrepreneurship, organizational behavior, and management, and the capstone business and strategy courses in the undergraduate and graduate program. Dr. Davis' research interests include managing planned change in organizations; leadership; entrepreneurship; and, ethic, moral, and spiritual issues in organizations. He has had refereed journal articles published in each of these areas and is associate editor of the New England Journal of Entrepreneurship.

Before becoming a university professor, Dr. Davis was a principal with EDS' E. Solutions Consulting organization, where he was responsible for worldwide delivery of organization transformation, business process reengineering (BPR), strategic planning and management, and change management consulting services to major corporations and government agencies. Dr. Davis continues to consult to companies worldwide, with a particular emphasizes on small and family-owned businesses. 